\title{
Wild Carrot Oil Extract is Selectively Cytotoxic to Human Acute Myeloid Leukemia Cells
}

\author{
Mirna Tawil', Amira Bekdash¹, Mohammad Mroueh ${ }^{2}$, Costantine F Daher ${ }^{1}$, \\ Ralph J Abi-Habib ${ }^{1}$
}

\begin{abstract}
Background: In this study, we used Daucus carota oil extract (DCOE) to target acute myeloid leukemia (AML) cells. All the AML cell lines tested were sensitive to the extract while peripheral mononuclear cells were not. Analysis of mechanism of cell death showed an increase in cells positive for annexin $V$ and for active caspases, indicating that DCOE induces apoptotic cell death in AML. Inhibition of the MAPK pathway decreased sensitivity of AML cells to DCOE, indicating that cytotoxicity may be dependent on its activity. In conclusion, DCOE induces selective apoptosis in AML cells, possibly through a MAPK-dependent mechanism.
\end{abstract}

Keywords: AML - Daucus carota - apoptosis - MAPK

Asian Pac J Cancer Prev, 16 (2), 761-767

\section{Introduction}

Acute myeloid leukemia (AML) is one of the most common leukemias in adults with an estimated 13,780 newly diagnosed cases and an estimated 10,200 deaths in the US in 2012 (American Cancer Society, 2012). Though a high proportion of AML patients enter complete remission following combination induction and consolidation chemotherapy, most patients eventually relapse due to persistence of chemotherapy-resistant blasts in the bone marrow (Bennett et al., 2002). Hence, alternative approaches employing novel mechanisms for targeting AML blasts are being actively sought.

Natural products and plant extracts have been investigated extensively for potential anti-cancer activity in a number of solid and hematological malignancies, including AML, CML, Hodgkin's and non-Hodgkin's lymphomas and lymphoid leukemias (Omoregie et al., 2013; Ramkumar et al., 2013; Asmaa et al., 2014). Also, natural products and plant extracts have been investigated for their ability to protect against radiation-induced toxicity (Kma, 2014). Importantly, A number of plantderived compounds have been shown to be active against AML cells such as icarised II, isolated from the stems and leaves of Epimedium koreanum, securinine, isolated from the root of Securinega suffruticosa, and flavopiridol, isolated from the stem bark of Amoora rohituka and Dysoxylum binectariferum (Nelson et al., 2006; Gupta et al., 2011; Kang et al., 2012). However, the potential of naturally occurring products in AML has not been fully explored yet, hence the need for identifying novel plantderived compounds for potential anti-AML activity.
Wild carrot, Daucus carota L. ssp. carota (Apiaceae), is one of many umbilliferous plants growing around the world (Van Wyk et al., 2004). The plant is edible when young but the root gets tough and woody when matured. In Lebanon, the plant is part of folk medicine for the treatment of cancer, gastric ulcer, diabetes, muscle and back pain, and for enhancing liver function and immune system. The essential oil of wild carrot obtained from the aerial part of the plant at the end of the flowering stage was reported to have antimicrobial and antifungal activities (Staniszewka et al., 2005; Rossi et al., 2007; Maxia et al., 2009). Wild carrot was also reported to possess antilithic, diuretic, and carminative properties, and has been used traditionally to treat urinary calculus, cystitis, gout, and lithuria (Barnes, 1998; Thomas et al., 2001; Rossi et al., 2007). In European folk medicine, the volatile oil from wild carrot is used as an antiseptic and anti-inflammatory remedy for cystitis and prostatitis (Hoffman, 1990). Additionally, it was demonstrated that the dichloromethane-methanol extract of the wild carrot flower possesses significant antioxidant activity (Akgul et al., 2009). Similarly, several studies have reported that a new type of sesquiterpene isolated from the fruits of wild carrot displays cytotoxic activity against a number of human gastric cancer cell lines (Wei et al., 2009).

Recently, we reported that the aqueous and methanolic extracts of the wild carrot umbels exhibit anti-inflammatory and antiulcer activities (Wehbe et al., 2009). We also found that Daucus carota oil extract (DCOE) has anti-tumor activity in a DMBA/TPA skin carcinogenesis model in mice in addition to anti-cancer and antioxidant activity against a wide range of tumor types including human 
colon (HT-29, Caco-2) and breast (MCF-7, MDAMB-231) cancer cell lines (Zeinab et al., 2011; Shebaby et al., 2013). However, the effects if DCOE have not been investigated yet in hematological malignancies. In this study, we investigate the potential for targeting human AML cell lines with DCOE and determine its underlying mechanism of action.

\section{Materials and Methods}

\section{Preparation of daucus carota oil extract:}

Daucus carota oil extract (DCOE) was prepared using Methanol/Acetone (1:1) extraction of the plant umbel as described previously (Zeinab et al., 2011). Briefly, mature umbels of Daucus carota (Linnaeus) ssp. carota were collected in August from their natural habitat in Lebanon. No specific permission was required to collect the plant from the particular locations in which it grows. The field studies consisted of collecting mature Daucus carota umbels only, hence did not involve endangered or protected species. The plant was identified according to the characteristics described in 'Handbook of Medicinal Herbs'.8 Stripped umbels were air dried in the shade and then cut into small pieces for oil extraction. Leaves were soaked in methanol/acetone (1:1) and the extract was then filtered and evaporated to dryness under reduced pressure. The residue was centrifuged, and the oil was dried over anhydrous sodium sulfate. The final yield $(3.47 \%)$ was stored in a closed amber bottle at $4^{\circ} \mathrm{C}$ until used.

\section{Cells and cell lines}

Human AML cell lines HL60, U937, ML1, ML2, Mono-Mac-1, Mono-Mac-6, KG-1, MV-4-11, TF1-vRaf, TF1-vSrc and TF1-HaRas were grown as described previously (Abi-Habib et al., 2004).

Human peripheral blood mononuclear cells (PBMCs) were isolated using Ficoll-Paque gradient as described previously (Tanios et al., 2013). Peripheral blood samples were collected from healthy adult individuals based on approval by the Committee on Human Subjects in Research (CHSR) of the Lebanese American University and following written informed consent by the donors. Briefly, $10 \mathrm{ml}$ of blood were diluted 3-fold in dilution buffer (phosphate buffered saline, 2 mM EDTA), layered carefully over ficoll-paque and centrifuged at $4500 \mathrm{rpm}$ for $20 \mathrm{~min}$. The layer corresponding to PBMCs was isolated, transferred to $45 \mathrm{ml}$ of dilution buffer, centrifuged twice at $3000 \mathrm{rpm}$ for $20 \mathrm{~min}$ at $20^{\circ} \mathrm{C}$ and the resulting pellet re-suspended in $10 \mathrm{ml}$ growth media.

\section{Proliferation inhibition assay (cytotoxicity)}

Sensitivity of AML cell lines and normal human PBMCs to Daucus carota oil extract (DCOE) was determined using a proliferation inhibition assay as described previously (Abi-Habib et al., 2005). Briefly, aliquots of 104 cells/well, in $100 \mu \mathrm{l}$ cell culture medium ( $10^{5}$ cells/well in $100 \mu 1$ media for PBMCs), were plated in a flat-bottom 96-well plate (Corning Inc. Corning, NY). Then, $50 \mu \mathrm{l}$ DCOE in DMSO, or DMSO alone, in media were added to each well to yield concentrations ranging from $100 \mu \mathrm{g} / \mathrm{mL}$ to $0.5 \mathrm{ng} / \mathrm{mL}$. Following a $48 \mathrm{~h}$ incubation ( $24 \mathrm{~h}$ incubation only for PBMCs) at $37^{\circ} \mathrm{C} / 5 \%$ $\mathrm{CO}_{2}, 50 \mu \mathrm{l}$ of XTT cell proliferation reagent (Roche, Basel, Switzerland) were added to each well and the plates incubated for another $4 \mathrm{~h}$. Absorbance was then read at 450 $\mathrm{nm}$ using a microplate reader (Thermo Fisher Scientific, Waltham, MA). Nominal absorbance and percent maximal absorbance were plotted against the log of concentration and a non-linear regression with a variable slope sigmoidal dose-response curve was generated along with IC50 using GraphPad Prism 5 software (GraphPad Software, San Diego, CA).

\section{Cell cycle analysis}

The impact of DCOE treatment on the cell cycle of AML cells was determined using Propidium Iodide (PI)staining, as described previously (Kassab et al., 2013). Briefly, cells incubated with 2 different concentrations of DCOE (40 and $5 \mu \mathrm{g} / \mathrm{mL}$ ) or media alone for 24 and $48 \mathrm{~h}$ at $37^{\circ} \mathrm{C} / 5 \% \mathrm{CO}_{2}$, were harvested and fixed in $70 \%$ ethanol for a minimum of $24 \mathrm{~h}$, at $-20^{\circ} \mathrm{C}$. Cells were then incubated in $500 \mu \mathrm{l}$ PI staining solution $(50 \mu \mathrm{g} / \mathrm{ml})$ for $40 \mathrm{~min}$ at $37^{\circ} \mathrm{C}$. Samples were then read on a C6 flow cytometer (BD Accuri, Ann Arbor, MI) and total cell DNA content was measured on FL2-H. Percent of cells in G0/ $\mathrm{G} 1, \mathrm{~S}$ and $\mathrm{G} 2 / \mathrm{M}$ phase was determined in control cells and in cells treated with the 3 different concentrations of DCOE following gating on width versus forward scatter.

\section{Analysis of cell cytotoxicity}

Determination of apoptotic versus non-apoptotic cell death was carried out using an Annexin V-fluorescin Isothiocyanate (Annexin V-FITC) and Propidium Iodide (PI) labeled apoptosis/necrosis detection kit (Abcam, Cambridge, MA) and a FITC-conjugated active caspase inhibitor (ApoStat Apoptosis Detection Kit, R\&D Systems, Abingdon, England), as described previously (Kassab et al., 2013). Briefly, cells were incubated with either $100 \mu \mathrm{l}$ of medium alone (control cells) or medium containing two different concentrations of DCOE (as described above under cell cycle analysis) for 6 and $24 \mathrm{~h}$ (for active caspase staining) and for 6, 24 and $48 \mathrm{~h}$ (for annexin V/PI staining) at $37^{\circ} \mathrm{C} / 5 \% \mathrm{CO}_{2}$. Cells were then harvested and incubated with a FITC-conjugated annexin $\mathrm{V}$ antibody $(2.5 \mathrm{mg} / \mathrm{ml})$ and $\mathrm{PI}(5 \mathrm{mg} / \mathrm{ml})$ in antibody binding buffer for $45 \mathrm{~min}$ at $37^{\circ} \mathrm{C}$ or incubated with 0.5 $\mu \mathrm{g} / \mathrm{ml}$ of apostat for $30 \mathrm{~min}$ then harvested. Cells were then read using a C6 flow cytometer. Annexin V/PI data was analyzed on FL1-H versus FL2-H scatter plot and active caspases were detected on FL1-H. Unstained cells were used as negative control. Cells with positive annexin V staining, negative PI staining and positive active caspase staining were considered apoptotic, while cells positive for both annexin V and PI staining and negative for active caspase staining were considered non-apoptotic.

\section{Inhibition assays}

AML cells were incubated with DCOE $(40 \mu \mathrm{g} / \mathrm{ml})$ in the presence or absence of the small molecular weight mitogen-activated protein/extracellular signal-regulated kinase kinase 1/2 (MEK1/2) inhibitor U0126 (Cell Signaling Technology, Danvers, MA). Briefly, 104 cells/ 
well were plated in $100 \mu$ l of medium in a flat-bottom, 96-well plate. Then $100 \mu$ l of either medium alone (control cells) or medium containing DCOE (40 $\mu \mathrm{g} / \mathrm{mL})$, U0126 (20 and $50 \mu \mathrm{M}$ ) or a combination of the above were added. Cells were then incubated for $48 \mathrm{~h}$ at $37^{\circ} \mathrm{C} / 5 \% \mathrm{CO}_{2}$ followed by the addition of $50 \mu \mathrm{l}$ of XTT cell proliferation reagent (Roche, Basel, Switzerland). Cells were incubated for another $4 \mathrm{~h}$ and absorbance was read at $450 \mathrm{~nm}$ using a 96-well plate reader (Thermo Fisher Scientific, Waltham, MA). Data was analyzed using GraphPad Prism V software (GraphPad Software, San Diego, CA). Total absorbance and percent absorbance of controls were compared between the different treatment groups.

\section{Intracellular staining and flow cytometry analysis}

Activation of the MEK1/2-ERK1/2 pathway in AML cell lines was assessed by determining the presence or absence of phospho-MEK1/2 using flow cytometry as described previously (Kassab et al., 2013). Approximately $3 \times 106$ cells were fixed in $70 \%$ ethanol for 15 min. Cells were then incubated with a 1/100 dilution of anti-phosphoERK1/2 (Ser 217/221) rabbit monoclonal antibodies (Cell Signaling Technology, Danvers, MA) in antibody binding buffer for $1 \mathrm{~h}$ at $37^{\circ} \mathrm{C}$, followed by a 30 -minute incubation with a 1/100 dilution of a FITC-conjugated mouse antirabbit polyclonal antibody (Santa Cruz Biotechnology, Santa Cruz, CA). Fixed cells stained only with FITCconjugated mouse anti-rabbit polyclonal antibody were used as isotypic control. Samples were then analyzed using a C6 flow cytometer (BD Accuri, Ann Arbor, MI). Positivity for the presence of phospho-ERK1/2 was determined using the ratio of fluorescence intensity (RFI) between the mean fluorescence intensity (MFI) of the stained cells and the MFI of the isotypic control. RFI $\geq 2$ was considered positive.

\section{Results}

Cytotoxicity of Daucus carota oil extract

DCOE was cytotoxic to all 11 AML cell lines with IC50 values ranging from 1.0 to $26.2 \mu \mathrm{g} / \mathrm{mL}$ and a percent
Table 1. Sensitivity of Human AML Cell Lines to DCOE

\begin{tabular}{lc}
\hline Cell line & DC crude oil extract $(\mathrm{IC} 50 ; \mu \mathrm{g} / \mathrm{mL})$ \\
\hline U937 & 1 \\
KG-1 & 1 \\
HL60 & 5.5 \\
TF1-VSrc & 7.3 \\
Mono-Mac-6 & 12.4 \\
Mono-Mac-1 & 13.2 \\
TF1-VRaf & 14.4 \\
MV-4-11 & 14.9 \\
ML1 & 19.6 \\
TF1-HaRas & 26 \\
ML2 & 26.2 \\
Normal PBMCs & $>100$ \\
\hline
\end{tabular}

cell kill at highest concentration ranging from 70 to $96 \%$ (Figure 1). To exclude any contribution of DMSO, the excipient used to re-suspend the extract, to the cytotoxicity of DCOE, we tested the effects of DMSO alone, at an equivalent volume, on the panel of AML cells. DMSO alone did not cause any significant cytotoxicity, hence excluding its contribution to the observed cytotoxicity of DCOE to human AML cell lines (Table 1).

Normal human peripheral blood mononuclear cells (PBMCs) were not sensitive to DCOE with an IC50 > 100 $\mu \mathrm{g} / \mathrm{mL}$ and a percent cell kill at the highest concentration $\leq 50 \%$ ) (Figure 1).

\section{Cell cycle effect of daucus carota oil extract}

In order to determine whether DCOE induces cell cycle arrest in AML cells, we determined the cell cycle status of a subset of AMLcell lines (ML1, ML2 and U937) following 24 and $48 \mathrm{~h}$ incubation with two different concentrations of extract. None of the cell lines tested showed any effect of DCOE treatment on cell cycle at either concentration and at both 24 and $48 \mathrm{~h}$ incubation (Figure 2A and B). The fraction of cells in both the G0/G1 and G2/M phases decreased with increasing concentrations of DCOE. This was accompanied by an increase in the fraction of cells in the pre-G0/G1 phase ( $>95 \%$ of total events) at the
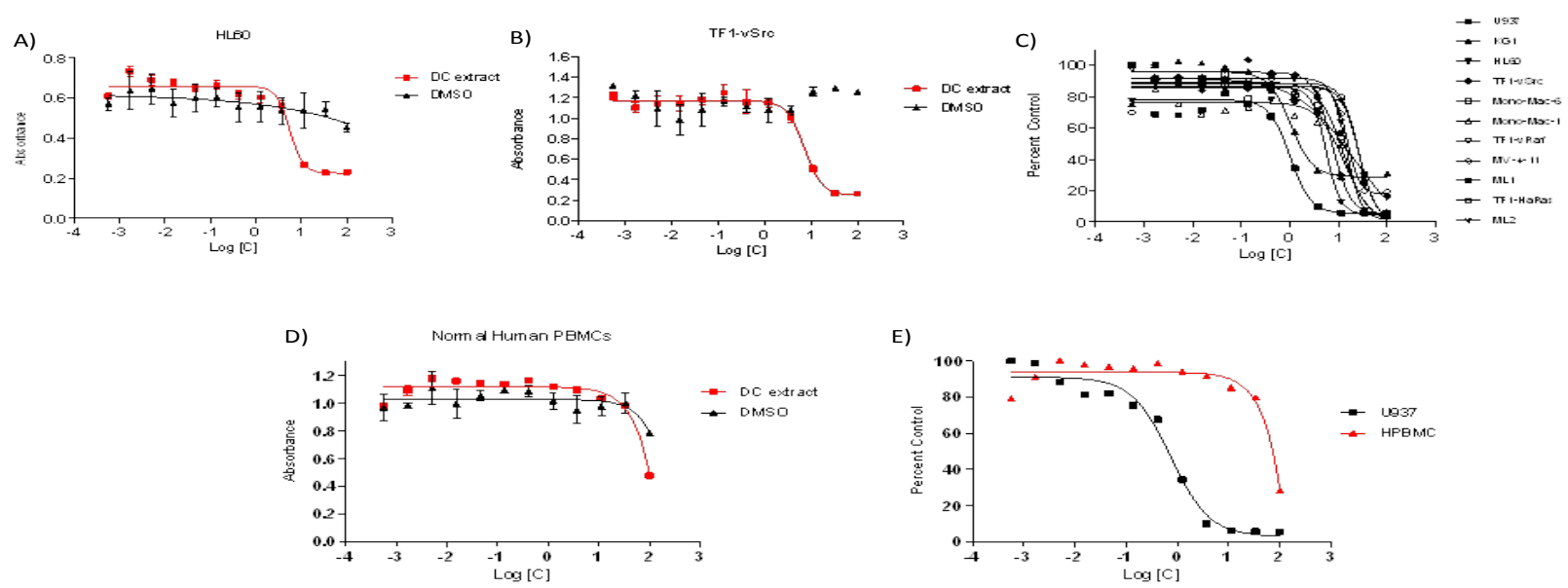

Figure 1. Non-Linear Regression Curves of DCOE (square) and DMSO (triangle) on Human AML Cell Lines. Two representative cell lines HL60 (A) and TF1-vSrc (B) are sensitive to DCOE. C) Compilation of DCOE non-linear regression curves on all AML cell lines tested. D) Non-linear regression curves of DCOE (square) and DMSO alone (triangle) on human normal PBMCs. E) Comparison of non-linear regression curves of DCOE on U937 cells and human normal PBMCs 


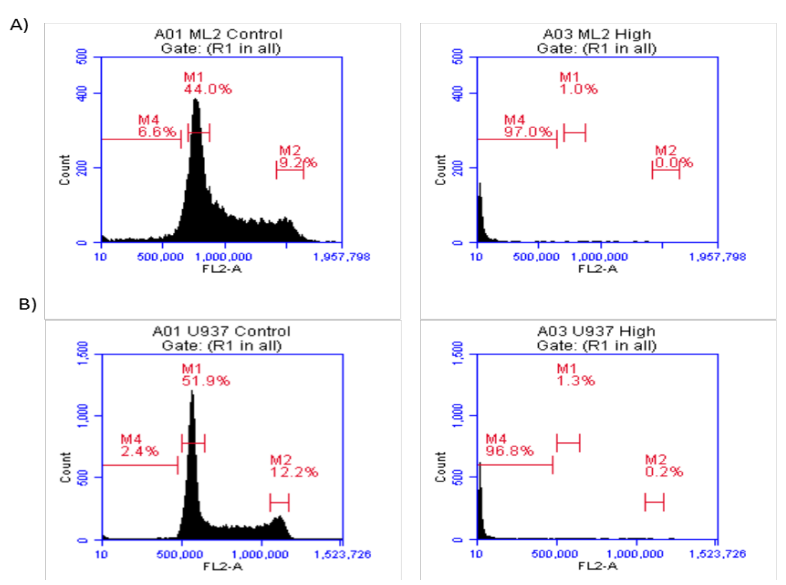

Figure 2. Cell Cycle Analysis of the ML2 (A) and U937 (B) AML Cell Lines Following Treatment with DCOE. Control cells are represented in the left panels and cells treated with $40 \mu \mathrm{g} / \mathrm{mLDCOE}$ for $48 \mathrm{~h}$ in the right panels. Cells are gated on width versus forward scatter (R1). Cells in G0/G1 are gated M1, G2/M are gated M2 and pre-G0/G1 (dead) are gated M4

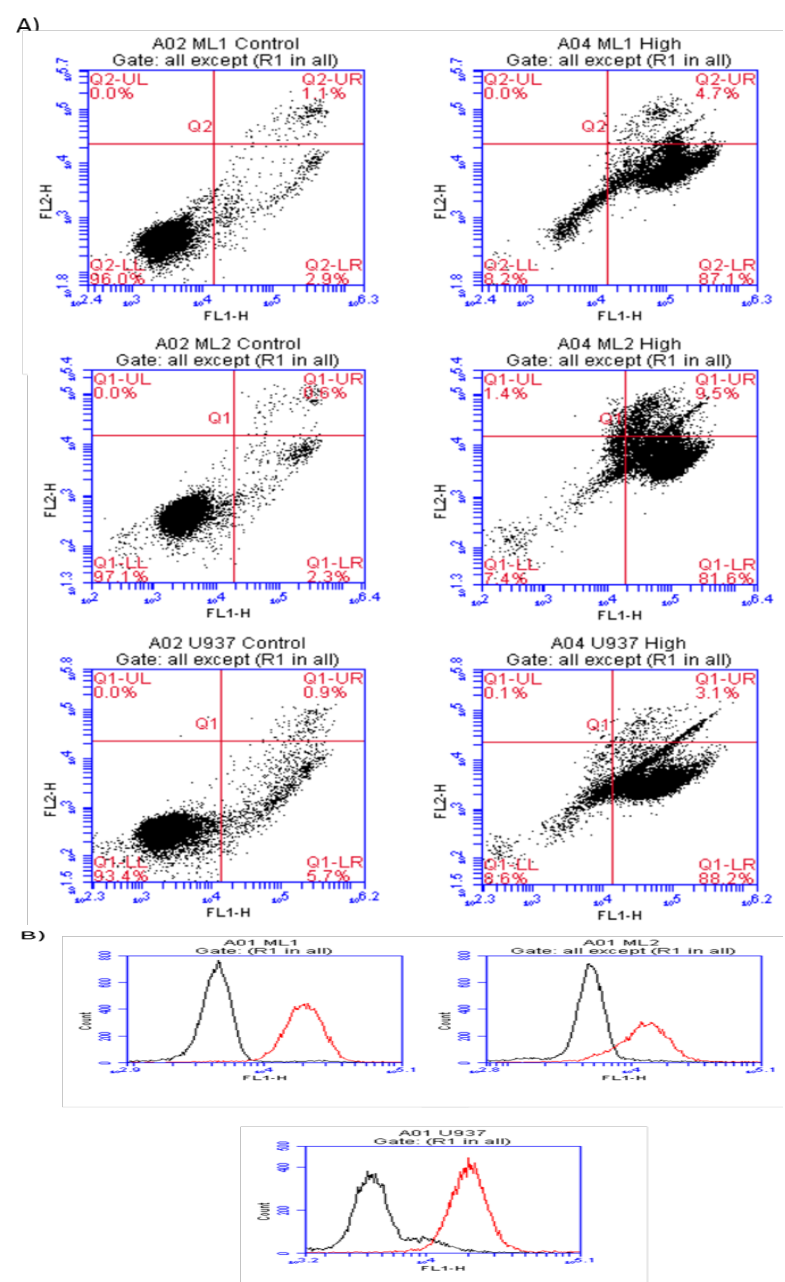

Figure 3. Analysis of DCOE-Mediated Cytotoxicity in ML1, ML2 and U937 Cells Using Annexin V/PI (A) and Active Caspase Staining (B). All 3 cell lines incubated with $40 \mu \mathrm{g} / \mathrm{mL}$ DCOE for $48 \mathrm{~h}$ (right panel) stained positively with annexin V (FL1-H) and negatively with PI (FL2-H). Incubation of DCOE-treated ML1, ML2 and U937 cells with a cell permeable, FITC-conjugated active caspase inhibitor revealed high levels of caspase activation following $24 \mathrm{~h}$ incubation with the extract (red) highest concentrations of the extract at both 24 and 48 $\mathrm{h}$ incubation, indicating that treatment induces complete cytotoxicity in the totality of treated cells.

\section{Analysis of cell death}

To determine the type of cell death observed following treatment of AML cells with DCOE, we tested for caspase activation and annexin V/PI staining, in a subset of cell lines (ML1, ML2 and U937), treated with two different concentrations of extract ( 40 and $5 \mu \mathrm{g} / \mathrm{mL}$ ) for 6,24 and $48 \mathrm{~h}$. In all three cell lines, a dose-dependent increase in the percentage of cells with positive annexin $\mathrm{V}$ staining and negative PI staining was observed, at all the time points tested, indicating apoptotic cell death (Figure 3). Staining for active caspases, following treatment with DCOE, revealed a dose-dependent increase in caspase activation, in all AML cell lines tested, following treatment with the extract for 6 and $24 \mathrm{~h}$ (Figure 3). The percentage of cells staining positive for the presence of active caspases increased from $2.4 \%, 3.2 \%$ and $10.1 \%$ in non-treated cells to $88 \%, 67.7 \%$ and $92.8 \%$ in cells treated with $40 \mu \mathrm{g} / \mathrm{mL}$ DC crude oil extract, for the ML1, ML2 and U937 cell lines, respectively, at $24 \mathrm{~h}$ post treatment. The increase in the percentage of cells showing positive annexin V staining and negative PI staining, in addition to caspase activation, indicates that DCOE induces caspase-dependent, apoptotic cell death in AML cell lines (Table 2).

\section{Inhibition of MAPK pathway}

In order to determine the impact of the inhibition of the Ras-Raf-MEK1/2-ERK1/2 pathway on the sensitivity of AML cell lines to DCOE, we tested the cytotoxicity of the extract on a subset of AML cell lines (ML2, U937 and $\mathrm{TF} 1-\mathrm{v} \mathrm{Src}$ ) in the presence of two different concentrations of the small molecular weight MEK1/2 inhibitor U0126. Co-Incubation of AML cell lines with both DCOE $(40 \mu \mathrm{g} /$ $\mathrm{mL}$ ) and $\mathrm{U} 0126(20$ and $50 \mu \mathrm{g} / \mathrm{mL}$ ) induced a statisticallysignificant, dose-dependent decrease in cytotoxicity compared to DCOE alone $(40 \mu \mathrm{g} / \mathrm{mL})$. Addition of 20 $\mu \mathrm{M}$ U0126 increased the percentage of surviving cells by a range of $13 \%$ to $21 \%$ compared to the extract alone, while addition of $50 \mu \mathrm{M}$ U0126 induced a more significant increase in the percentage of surviving cells ranging from $23 \%$ to $35 \%$, compared to DCOE alone, following a $48 \mathrm{~h}$ incubation (Figure 4). Furthermore, in one of the cell lines

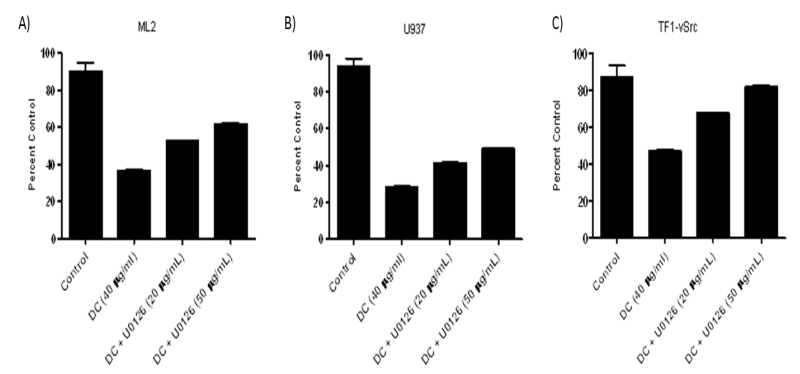

Figure 4. Sensitivity of AML Cell Lines to DCOE Alone and in Combination with U0126. AML cell lines ML2 (A), U937 (B) and TF1-vSrc (C) are sensitive to DCOE alone. Coincubation with the small molecular weight MEK1/2 inhibitor induces a statistically significant, dose-dependent decrease in the sensitivity of AML cells to the extract. 

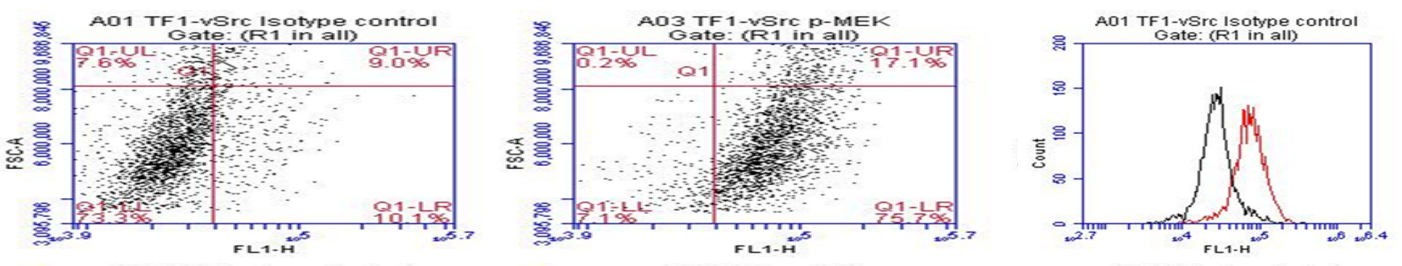

$\mathrm{RFI}=2.63$
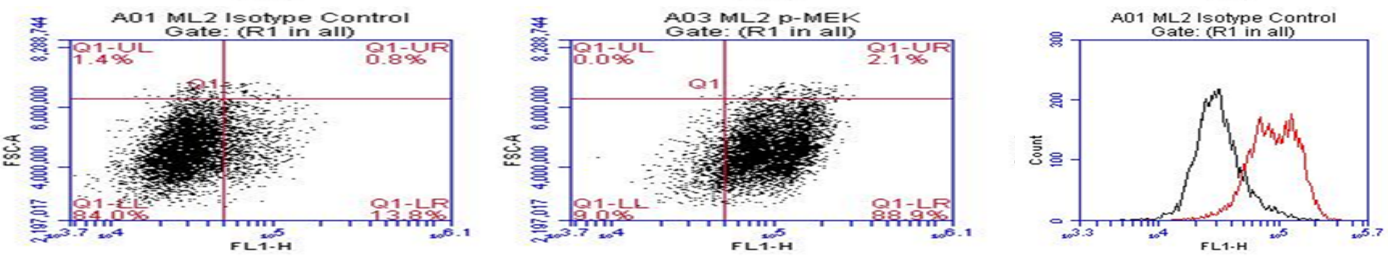

$\mathrm{RFI}=2.85$
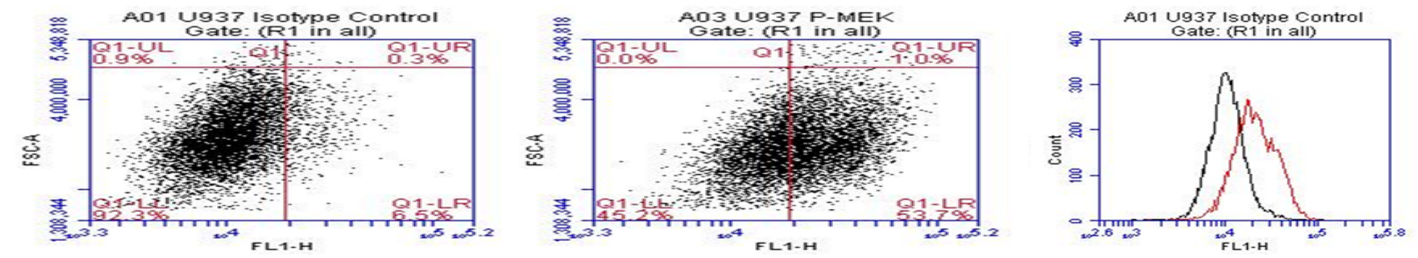

$\mathrm{RFI}=2.11$

Figure 5. Single Cell, Intracellular Staining of Phospho-MEK1/2 Using Flow Cytometry. ML2 (A), TF1-vSrc (B) and U937 (C) cells, which were rescued by U0126, were positive for phospho-MEK1/2 as evidenced by a ratio of fluorescence intensity (RFI) $>2$ between cells stained for phospho-MEK 1/2 and cells incubated with the isotype control (black). Cells are gated on width versus forward scatter (R2 and R3)

Table 2. Percent of AML Cells Positive for Annexin V Staining Following Treatment with DCOE

\begin{tabular}{lrrrc}
\hline Cell line & $\begin{array}{c}\text { Time } \\
\text { Point }\end{array}$ & $\begin{array}{c}\text { Non-treated } \\
\text { cells }\end{array}$ & $\begin{array}{c}\text { Cells treated } \\
\text { with 5 } \mu \mathrm{g} / \mathrm{mL}\end{array}$ & $\begin{array}{c}\text { Cells treated } \\
\text { with } 40 \mu \mathrm{g} / \mathrm{mL}\end{array}$ \\
\hline ML1 & $6 \mathrm{~h}$ & $4.90 \%$ & $5.40 \%$ & $48.20 \%$ \\
& $24 \mathrm{~h}$ & $4.50 \%$ & $5.50 \%$ & $66.80 \%$ \\
ML2 & $48 \mathrm{~h}$ & $2.90 \%$ & $5.10 \%$ & $87.10 \%$ \\
& $6 \mathrm{~h}$ & $8 \%$ & $42.80 \%$ & $42.70 \%$ \\
& $24 \mathrm{~h}$ & $3.90 \%$ & $23.80 \%$ & $68.20 \%$ \\
U937 & $48 \mathrm{~h}$ & $2.30 \%$ & $45.90 \%$ & $81.60 \%$ \\
& $6 \mathrm{~h}$ & $5.50 \%$ & $6.20 \%$ & $40.50 \%$ \\
& $24 \mathrm{~h}$ & $4.30 \%$ & $4.60 \%$ & $68.80 \%$ \\
& $48 \mathrm{~h}$ & $5.70 \%$ & $5.00 \%$ & $88.20 \%$ \\
\hline
\end{tabular}

tested (TF1-vSrc), addition of the $50 \mu \mathrm{M}$ U0126 led to the complete reversal of DCOE cytotoxicity with no statistical significance observed between survival of control cells and cells treated with the combination of DCOE and $50 \mu \mathrm{M}$ U0126 ( $\mathrm{p}=0.425)$ (Table 3). These results indicate that cytotoxicity of DCOE to AML cells is dependent on the activity of the Ras-Raf-MEK1/2-ERK1/2 pathway with the inhibition of this pathway significantly reducing the cytotoxic effects of the extract.

\section{Analysis of MAPK activation}

We examined the activation level of the MAPK pathway by determining the phosphorylation status of phospho-MEK1/2, in the subset of three AML cell lines used in the MAPK inhibition assay (ML2, U937 and TF1-vSrc). All three cell lines were positive for phosphoMEK1/2 (RFI= 2.85, 2.63 and 2.11 for ML2, TF1-vSrc and U937, respectively), demonstrating the presence of an active MAPK pathway in these cells (Figure 5). These findings match the results observed earlier in which coincubation with U0126 partially or completely rescued cells from DCOE-induced cytotoxicity and indicate that the activity of DCOE may require the presence of an active MAPK pathway.
Table 3. Percent Survival of AML Cells Treated with DCOE Alone $(40 \mu \mathrm{g} / \mathrm{mL})$ or in Combination with $\mathrm{U0126}(20$ and $50 \mu \mathrm{M})$

\begin{tabular}{lccc}
\hline Cell line & $\begin{array}{c}\text { DC crude } \\
\text { oil extract }\end{array}$ & $\begin{array}{c}\text { DC extract+ } \\
20 \mu \mathrm{M} \mathrm{U0126} \\
(\mathrm{p}<0.0001)\end{array}$ & $\begin{array}{c}\text { DC extract+ } \\
50 \mu \mathrm{M} \text { U0126 } \\
(\mathrm{p}<0.0001)\end{array}$ \\
\hline U937 & $29 \%$ & $42 \%$ & $50 \%$ \\
TF1-VSrc & $47 \%$ & $68 \%$ & $82 \%$ \\
ML2 & $37 \%$ & $53 \%$ & $62 \%$ \\
\hline
\end{tabular}

\section{Discussion}

Investigating natural products and plant extracts for potential anti-cancer activity has been steadily rising over the last decades. In fact, several plant-derived natural compounds, or their derivatives, have been approved for the treatment of a wide range of solid and hematological malignancies including vinblastine used for the treatment of bladder cancer, breast cancer and Hodgkin's lymphoma, vincristine used for the treatment of lymphoid leukemias and lymphomas and etoposide used for the treatment of lung cancer, testicular cancer and certain types of Leukemias and lymphomas (Bates et al., 2013; Watanabe et al., 2013; Trifilio et al., 2013). In addition, several novel plant-derived natural products with significant anti-cancer activity against a wide array of tumor types have been recently isolated, identified and characterized including, among others, noscapine, bruceantin and silvestrol (Cuendet et al., 2004; Madan et al., 2013; Alachkar et al., 2013). One of the hematological malignancies for which novel treatments are urgently needed, and in which the investigation of plant-derived compounds has been relatively limited thus far is acute myeloid leukemia (AML).

In this study, we have shown that DCOE possesses a robust anti-AML activity as evidenced by its cytotoxicity to a panel of 11 human AML cell lines. DCOE was found 
to be highly cytotoxic to all eleven cell lines tested. The observed anti-leukemic effects of DCOE match the effects previously seen with this extract against colon and breast cancer cell lines and confirm its wide-range anti-cancer activity (Zeinab et al., 2011; Shebaby et al., 2013). Furthermore, we have shown that DCOE selectively targets AML cell lines while sparing normal blasts with human PBMCs being more than 5-fold less sensitive to the cytotoxic effects of the extract compared to AML cells. This is encouraging since it indicates that the potential active compound in Daucus carota oil extract may be selectively cytotoxic to AML cells and, subsequently, possess a large therapeutic window in this disease. Moreover, we have demonstrated that the anti-proliferative effects observed following treatment of AML cells with DCOE are entirely due to the cytotoxicity of the extract to AML cells with no contribution of cell cycle arrest, since cell cycle analysis revealed the absence of cell cycle arrest following treatment. The cytotoxicity of DCOE and the total absence of cytostatic effects support the robust antileukemic activity observed with this extract and are in line with previous findings using DCOE in a number of solid malignancies including breast and colon cancer (Shebaby et al., 2013). We have also shown that treatment of AML cells with DCOE induces apoptotic cell death. This was demonstrated by positive annexin V staining, persistence of membrane integrity (negative PI staining) and the presence of active caspases following treatment with DCOE. These findings are in line with results obtained by other groups testing novel plant-derived natural products in AML, such as Icariside II, shown to induce apoptosis in the U937 AML cell lines (Gupta et al., 2011).

In addition, we have tried to decipher some of the molecular mechanisms underlying the cytotoxicity of DCOE to AML cells by investigating the effects of the combination of DCOE and the small molecular weight MEK1/2 inhibitor U0126. We originally hypothesized that the combination of DCOE and U0126 may show additive/synergistic effects in AML, particularly since we have previously shown that the majority of AML cell lines are sensitive to the inhibition of the MAPK pathway (Kassab et al., 2013). However, our results showed that the combination of DCOE and U0126 was antagonistic with cells being less sensitive to DCOE in the presence of U0126, regardless of their sensitivity to U0126 alone. In addition, we have shown that all cells rescued by coincubation with U0126 have an active MAPK pathway as evidenced by the presence of phosphorylated MEK1/2. Though unexpected, these results indicate that the Ras-Raf-MEK1/2-ERK1/2 pathway is active in AML cells and that its inhibition decreases the sensitivity of AML cells to DCOE and even lead to complete rescue in certain cell lines. These findings indicate that the cytotoxicity of DCOE to AML cells may be dependent on the activity of the MAPK pathway with a decrease in activity associated with a lower sensitivity to the extract. Since the inhibition of the MAPK pathway may lead to a decrease in cell proliferation, this might indicate that DCOE-induced cytotoxicity to AML cells could be proliferation dependent. Additional studies will be carried out to investigate in further detail the mechanisms of
DCOE cytotoxicity and the underlying mechanisms of its potent anti-AML activity.

In conclusion, we have shown that the Daucus carota oil extract is selectively cytotoxic to human AML cell lines and induces caspase-dependent apoptotic cell death. Furthermore, we have shown that DCOE-induced cytotoxicity may be dependent on the activity of MAPK pathway.

\section{Acknowledgements}

The authors would like to thank Wassim Shebaby for preparing the extract.

\section{References}

Abi-Habib RJ, Liu S, Bugge T, Leppla SH, Frankel AE (2004). A urokinase-activated recombinant diphtheria toxin targeting the granulocyte-macrophage colony-stimulating factor receptor is selectively cytotoxic to human acute myeloid leukemia blasts. Blood, 104, 2143-48.

Abi-Habib RJ, Urieto JO, Liu SH, et al (2005). Braf status and mitogen-activated protein/extracellular signal-regulated kinase kinase $1 / 2$ activity indicate sensitivity of melanoma cells to anthrax lethal toxin. Mol Cancer Ther, 4, 1303-10.

Akgul Y, Aktas LY, Anil H (2009). Compounds from flowers of Daucus carota L. SSP. carota and their antioxidant activity. Chem Nat Compd, 45, 889-92.

Alachkar H, Santhanam R, Harb JG, et al (2013). Silvestrol exhibits significant in vivo and in vitro antileukemic activities and inhibits FLT3 and miR-155 expressions in acute myeloid leukemia. J Hematol Oncol, 6, 21.

American Cancer Society: Cancer Facts and Figures 2012. Atlanta, Ga: American Cancer Society.

Asmaa M,Al-Jamal H, Ang C, et al (2014). Apoptosis induction in MV4-11 and K562 human leukemic cells by Pereskia sacharosa (Cactaceae) leaf crude extract. Asian Pac J Cancer Prev, 15, 475-81.

Barnes J (1998). Herbal medicine. Pharm J, 260, 344-8.

Bates DJ, Danilov AV, Lowrey CH, Eastman A (2013). Vinblastine rapidly induces NOXA and acutely sensitizes primary chronic lymphocytic leukemia cells to ABT-737. Mol Cancer Ther, 12, 1504-14.

Bennett JM, Kouides PA, Forman SJ (2002). The myelodysplastic syndromes: morphology, risk assessment, and clinical management. Int J Hematol, 2, 228-38.

Cuendet M, Christov K, Lantvit DD, et al (2004). Multiple myeloma regression mediated by bruceantin. Clin Cancer Res, 10, 1170-9.

Gupta K, Chakrabarti A, Rana S, et al (2011). Securinine, a myeloid differentiation agent with therapeutic potential for AML. PLoS One, 6, 21203.

Hoffman D (1990). The new holistic herbal (3rdedn). Element Pres, Shaftesbury Dorset: Great Britain.

Kang SH, Jeong SJ, Kim SH, et al (2012). Icariside II induces apoptosis in U937 acute myeloid leukemia cells: role of inactivation of STAT3-related signaling. PLoS One, 7, 28706.

Kassab E, Darwish M, Timsah Z, et al (2013). Cytotoxicity of anthrax lethal toxin to human acute myeloid leukemia cells is non-apoptotic and dependent on extracellular signalregulated kinase 1/2 activity. Transl oncol, 6, 25-32.

Kma L (2014). Plant extracts and plant-derived compounds: promising players in countermeasure strategy against radiological exposure: a review. Asian Pac J Cancer Prev, 15, 2405-25. 
Madan J, Pandey RS, Jain V, et al (2013). Poly (ethylene)glycol conjugated solid lipid nanoparticles of noscapine improve biological half-life, brain delivery and efficacy in glioblastoma cells. Nanomedicine, 9, 492-503.

Maxia A, Marongiu B, Piras A, et al (2009). Chemical characterization and biological activity of essential oils from Daucus carota L. subsp. carota growing wild on the Mediterranean coast and on the Atlantic coast. Fitoterapia, 80, 57-61.

Nelson DM, Joseph B, Hillion J, et al (2011). Flavopiridol induces BCL-2 expression and represses oncogenic transcription factors in leukemic blasts from adults with refractory acute myeloid leukemia. Leuk Lymphoma, 52, 1999-2006.

Omoregie SN, Omoruyi FO, Wright VF, Jones L, Zimba PV (2013). Antiproliferative activities of lesser galangal (Alpinia officinarum Hance Jam1), Turmeric (Curcuma longa L.), and Ginger (Zingiber officinale Rosc.) against acute monocytic leukemia. J Med Food, 16, 647-55.

Ramkumar KM, Manjula C, Elango B, et al (2013). In vitro cytotoxicity of Gymnema montanum in human leukaemia HL-60 cells; induction of apoptosis by mitochondrial membrane potential collapse. Cell Prolif, 46, 263-71.

Rossi P-G, Bao L, Luciani A, et al (2007). (E)-methylisoeugenol and elemicin: antibacterial components of Daucus carota L. essential oils against campylobacter jejuni. J Agric Food Chem, 55, 7332-6.

Shebaby WN, El-Sibai M, Smith KB, et al (2013). The antioxidant and anticancer effects of wild carrot oil extract. Phytother Res, 27, 737-44.

Staniszewska M, Kula J, Wieczorkiewicz M, Kusewicz D (2005). Essential oils of wild and cultivated carrots - the chemical composition and antimicrobial activity. J Essent Oil Res, 17, 579-83.

Tanios R, Bekdash A, Kassab E, et al (2013). Human recombinant arginase I(Co)-PEG5000 [HuArgI(Co)-PEG5000]-induced arginine depletion is selectively cytotoxic to human acute myeloid leukemia cells. Leuk Res, 37, 1565-71.

Thomas KJ, Nicholl JP, Coleman P (2001). Use and expenditure on complementary medicine in England: a population based survey. Complement Ther Med, 9, 2-11.

Trifilio S, Zhou Z, Altman J, et al (2013). Dose-intense etoposidecyclophosphamide without stem cell transplantation for patients with intermediate and high cytogenetic risk primary refractory and relapsed acute myeloid leukemia. Leuk Res, 37, 872-6.

Van Wyk B-E, Wink M. 2004. Medicinal plants of the world. Briza Publications: Pretoria, South Africa.

Watanabe R, Tomita N, Kishimoto K, et al (2013). Absolute monocyte count in follicular lymphoma patients treated with rituximab plus cyclophosphamide, doxorubicin, vincristine, and prednisone. Leuk Res, 37, 1208-12.

Wehbe K, Mroueh M, Daher C (2009). The potential role of Daucus carota aqueous and methanolic extracts on inflammation and gastric ulcers in rats. J Comp Integ Med, 6, 16 .

Wei Fu H, Zhang L, Yi T, Lin Feng Y, Kui Tian J (2009). A new sesquiterpene from the fruits of Daucus carota L. Molecules, 14:2862-2867.

Zeinab RA, Mroueh M, Diab-Assaf M, et al (2011). Chemopreventive effects of wild carrot oil against 7,12-Dimethyl Benz(a)anthracene-Induced Squamous Cell Carcinoma in Mice. Pharm Biol, 49, 955-61. 